\title{
The Application of Character Values of Love, Discipline, and Honesty in Children Aged 4-6 Years
}

\author{
Kristianingsih $^{1, *}$ Adhimas Wahyu Agung Wijaya ${ }^{2}$
}

\author{
${ }^{1}$ Postgraduate School, Universitas Negeri Yogyakarta, Yogyakarta, Indonesia \\ ${ }^{2}$ School of Education, The University of Queensland, Brisbane, Australia \\ *Corresponding author. Email: kristianingsih04@gmail.com
}

\begin{abstract}
This study aims to describe: (1) the application of love, discipline, and honesty values in children aged 4-6 years and (2) the supporting and inhibiting factors for the application of three-character values in children aged 4-6 years in Kanisius Kotabaru Kindergarten, Yogyakarta. This study is a qualitative research employing a phenomenological approach. Data collection was done through interviews, observation and documentation. The data were validated using triangulation between participation, documentation, observation, and interview. The results of the study are (1) How to apply the value of love, discipline, and honesty that is by habituating, exemplary, environmental conditioning, and increasing awareness of the behaviour and speech guiding that is done through (a) The application of the value of love is seen in each before and after the activity through pray. The application of love also can be found through children weekly devotion/ PIA (Pendampingan Iman Anak) activities every Saturday. Furthermore, the love value is applied through giving and returning greetings, helping others who seem distressed, listening to the teacher's reprimand when children make mistakes, children are willing to give and apologize. Children also keeping in care school facilities, care for school pets, and care for school plants. (b) Application of the value of discipline that is when children comply with school rules, respect the rights of others, and be polite. (c) Application of honest values that is when the words of the child are in accordance with the actions of the child and are sporty when the child is playing games. (2) The supporting and inhibiting factors in implementing the character values are as follows :(a) good communication between teachers and parents, enabling environment (learning process is conducive), adequate facilities (chapel/praying room available, playing zone, fence available). (b) inhibiting factors are parenting style and inadequate number of teachers.
\end{abstract}

Keywords: Early childhood, character education, love, discipline, honesty, application character values,

early childhood Indonesia

\section{INTRODUCTION}

Early childhood is a sensitive period of child development and growth, widely known as the golden age. It is sensitive period because every child who is at an early age absorbs stimuli very quickly given to their development and growth. Sensitive or golden period in early childhood occurs in the age range of 0 to 6 years. It is important in this sensitive time to minimize obstacles or negative influences that can interfere with children's development and growth. An example of negative influence on children's development is bullying in any form received by the child.

Bullying, which is also called intimidation, evidently occurs at kindergarten. Bullying is a negative action carried out by someone or more and carried out repeatedly (Olweus, 1993, p. 4). Negative actions that occur in early childhood can affect adulthood period. Bullying has serious consequences for the child's future development. The effects of bullying include stress, depression, anxiety, and are more sensitive to the words and actions of others (Hidayati, 2012, p. 41).

Due to the negative impacts of bullying for early childhood development, it is pivotal to internalize positive character values in each child. The essence of value education (both character and moral) has a significant role to shape the child's personality so that he becomes a human being who is intellectually, emotionally and socially intelligent, kinetically smart, being a citizen and good and responsible citizens.

This research was conducted at Kanisius Kindergarten Kotabaru Yogyakarta because based on pre-survey results, Kanisius Kindergarten was able to maintain the character values that have been the virtue values in education since 1918, namely: the values of love, discipline, and honesty. In addition, the kindergarten orgnaises PIA (Child Faith Assistance) activities on Saturdays. Therefore, the researchers were interested in researching about the value of characters that exist in TK Kanisius Kotabaru Yogyakarta. 
This study aimed to (1) describe the application of the value of the character of love, discipline and honesty in children aged 4-6 years at TK Kanisius Kotabaru Yogyakarta and (2) describe the supporting and inhibiting factors the application of the value of the character of love, discipline and honesty in children aged 4-6 years at TK Kanisius Kotabaru Yogyakarta.

\section{LITERATURE REVIEW}

\subsection{Character Value in Early Childhood Education and the History of Kanisius}

TK Kanisius (Kanisius Kindergarten) is part of Yayasan Kanisius (Kanisius foundation), that is an old education institution in Java, founded in Muntilan in 1918 under name "Canisius Verenigining". At first, Kanisius foundation (include from Kindergarten-Senior Highschool) is built to give an opportunity to poor family to access education. TK Kanisius Kotabaru itself built around 1945 after Indonesian independence. The school vision and mission of TK Kanisius is same with vision of Yayasan Kanisius "to create Indonesian children who are smart and hold positive character values of caring others, community and nature". The school also has motto "Educating Children to Create Meaningful lives". This motto also means how to improve the quality of education and giving meaningful values and impact for others and community. Based on its vision and mission, this TK Kanisius also focuses on love, discipline and honesty values.

Based on Law No. 20, 2003 article 1 number 14 about National Education System, Early Childhood Education (ECE) is a coaching effort aimed at children from birth to six years old carried out through the provision of educational stimuli to help their growth and development physically and spiritually so that children have school readiness. Furthermore, Suyadi and Ulfa (2015, p. 17) asserted that early childhood education is the organization of education to facilitate child development and growth for all aspects of child development. Sujiono (2013) argues that early childhood education is an effort made by adults in creating an environment so that children can explore experiences. Taken together, early childhood education is a coaching effort undertaken by educators and parents through education aimed at ensuring that children are well stimulated in all aspects of their development. In this sense, children aspect of development includes character development

Specifically, there are several character values developed by Kanisius school, namely: love, discipline and honesty.

\subsubsection{Love}

Hermans (2017, p. 82) argues that the value of love is a concern, care, and sensitivity. Cordner (2016, p. 11) states that love is responsive to a reality. In this sense, children need to internalise their act of love in daily activities. So, the value of love is based on one's concern for the reality that occurs around him. In more detail, children can develop the character of love through caring for themselves and caring for others.

\subsubsection{Discipline}

Lickona (2012, p. 175) argues that discipline is respect for the rules, authority, and rights of others. Fadlillah (2012) states that discipline is an act of obedience and orderliness to rules or regulations. Discipline is a respect for the rules reflected into an action. Discipline is very essential to children future development to develop children selfcontrol.

\subsubsection{Honesty}

Soegeng, Abdullah, and Kasihadi (2016, p. 265) state that honesty is an attitude that reflects righteous hearts, is not cheating, and sincere. Samani and Hariyanto (2012, p. 51) argue that honesty is what it is, open, consistent between what is said and done (with integrity), brave because it is true and trustworthy. So, honesty is an attitude that is not cheating, open as it is, and has harmony between words and deeds.

\subsection{The Application of Character Values}

Saptono (2015, p. 98$)$ argues that in the strategies to apply character values can be through teacher lectures, interactive and reflective activeities, konsientiasi (children are invited to realize their existing values and correct it immediately) and examples. Fadlillah (2012) states that there are four methods in applying character values, namely exemplary, habituation, storytelling, and field trips. Muslich (2011) argues that in applying character values integration is needed in daily activities. The intended integration is through example, spontaneous activities, reprimands, environmental conditioning, and routine activities. The application of character values can be through direct example (the attitudes and words of teachers and parents) and indirectly (through stories), habituation, reprimand, environmental conditioning, and spontaneous activities.

Semiawan (2008, p. 10) argues that schools and teachers, the family environment and parents can recognize factors that influence the development and growth of children. Fadlillah (2012) states that genetic (genetic) and environmental factors also influence a child's development. Dewantara (2011, p. 70) argues that the education triangle system (family, school and youth) is a factor influencing children's education. Thus, supporting and inhibiting factors for child development, including in the application of character values to children include 
heredity (genetics) and environmental factors (family, school, and community).

\section{RESEARCH METHOD}

This research uses qualitative research by using a phenomenological approach. Denzin and Lincoln (in Moleong, 2011, p. 5) argue that qualitative research is research that uses a natural setting. The natural background in question is to interpret phenomena that occur and are carried out by involving various existing methods. Denscombe (2014) explains that qualitative research with a phenomenological approach is done by interpreting events and understanding the true meaning of one's personal experience. This research is focused on being able to interpret the application of the values of love, discipline, and honesty in children aged 4-6 years at TK Kanisius, KotaBaru, Yogyakarta.

Data sources in this study are primary and secondary data. According to Sugiyono (2010, p. 308), primary data come from data sources that directly provide data to data collectors (first-hand original data). Secondary data originate from data sources that do not directly provide data to data collectors (information that is collected by previous researcher on can be collect from database information/archive). In this study, primary data are obtained directly by data collectors in the form of words and actions from the principal, teachers, children, and parents. The secondary data are obtained indirectly by data collectors in the form of archives in TK Kanisius Kotabaru Yogyakarta.

Data collection techniques in this study are interviews, observation, and documentation. Data were collected through interviews with school principals, teachers and parents. Data through observations were obtained from direct observations of school principals, teachers and children. Meanwhile, with the technique of collecting data through documentation, the data generated in the form of photos of activities, proof of character values, learning plans, and history books for founding foundations.

The validity of the data used in this study is the extension of participation and triangulation. The extension of participation intended in this study is that researchers carry out research activities until they reach data saturation. Triangulation in this study was carried out by comparing the results of interview, observation and documentation data.

For analyzing the data, Creswell and Poth (2016) proposed a six-step analysis of qualitative research data with a phenomenological approach. The six steps are: (1) data managing, (2) reading and scraping, (3) describing, (4) classifying, (5) interpreting, (6) representing and visualizing. Data analysis in this research is carried out through these six stages. (1) Data managing is the stage where the researcher collects and organizes all the data that has been collected. (2) The intended reading and memoing is the stage where the researcher reads all collected data, makes marginal notes, and makes initial codes needed for the meaning of the data. (3) Describing is the stage for describing and interpreting the respondent's personal experience through eliminating data so that it stays at the research objective. (4) Classifying is the stage of classifying the meaning units of the data that have been described. (5) Interpreting is the step of granting the essence of the phenomenon under study. (6) Representing and visualizing, namely giving a narrative of the meaning of experience in the form of descriptions and images.

\section{RESULT AND DISCUSSION}

\subsection{The application of love, discipline, and honesty values in chidren aged 4-6 years at TK Kanisius Kotabaru Yogyakarta}

The introduction of love, honesty and discipline values is carried out in an integrated manner with daily activities. The method of application is through habituation, example, environmental conditioning (done with applause and singing), and increasing awareness of the behavior and speech that is made (spontaneous reprimand from the teacher and to give a deterrent effect the teacher will ask the child to sing a song that can remind the child of his mistakes).

\subsubsection{Love}

The main application of the value of love is love for God. This love for God can be seen from before and after doing learning activities: always praying first, besides that it is reflected on every Saturday devotion the holding of PIA (Pendampingan Iman Anak). PIA is a worship activity that is intended to strengthen the child's faith in God through reading the Bible and singing spiritual songs.

"Character education is already integrated in every lesson. Every Saturday we have children faith activity (PIA)"

The value of love is also applied to fellow human beings and the environment. The application is seen when children want to give and return greetings, help others who appear to be struggling, listen to what the teacher says when children make mistakes, and children want to share and apologize. The value of love for the environment can be seen from the children's attitude in protecting school facilities, caring for the school pets, and caring for the school plants.

\subsubsection{Discipline}

The application of the discipline value can be seen when children obey school rules (for example every Monday following ceremonies, coming to school on time, playing outside the class during recess), respect the rights of others (for example respecting others who are talking, not 
disturbing friends while eating), and show politeness (for example, say something without yelling).

\subsubsection{Honesty}

The value of honesty can be seen when the words and actions of children are in harmony or in accordance (for example children do their own work). The value can also be seen when children play games in a sportive manner (playing according to existing or agreed rules).

\subsection{Supporting and Inhibiting Factors of The Application of the Character Values of Love, Discipline and Honesty}

\subsubsection{Supporting factors}

Supporting factors in the application of the values of love, discipline, and honesty include (a) good communication between teachers and parents, (b) a conducive environment, (c) adequate facilities. Good communication between teachers and parents is indicated by the two way communication about children's development. The communication is not only through face-to-face, but it can also be through phone calls, text messages or online groups. The surrounding environment is also conducive, because the distance between the classroom and the highway is far enough, so that noise from vehicles does not really affect the child's learning process at the school. Adequate facilities include a chapel for children's and teacher's spiritual activities, a safe playroom equipped with a guardrail, and play equipment in which its materials and designs are not harmful to children.

\subsubsection{Inhibiting factors}

Inhibiting factors in the application of the values of love, discipline, and honesty are (a) parenting style, and (b) inadequate number of teachers. The parenting style in question is that every parent has authority in the method of educating their children. Sometimes, the parenting style and approach as well as the character values taught by parents are different from the character values developed at school. This caused a confusion for children whether they need to follow the rules at home or school. Inadequate number of teachers is also one of the inhibiting factors, because there are only two teachers for two classes, and they do all of the administrative affairs as well.

Based on the results, this research is in line with Fadlillah's (2012) and Muslich's (2011) research that there are several methods that can be used to introduce character values: exemplary, habituation (integrating in daily life), storytelling. This study also confirms that the application of character values can be through direct example (the attitudes and words of teachers and parents) and habituation. This provides evidence to previous studies by Semiawan (2008, p. 10), which found that the family environment and parents have a significant influence on the development and growth of children. Using Dewantara (2011, p. 70) triangle theory, this research found that there is no significant influence of youth in character development, but only the influence of school and family.

\section{CONCLUSION}

The application of character values of love, discipline and honesty can be carried out through habituation, which is immeresed in daily and weekly activities, exemplary, conditioning environment (safe, friendly, clean and supported with adequate numbers of teaching learning aids). Character development is also in line with TK Kanisius vision and mission and Yayasan Kanisius vision. The love and discipline values seem to be the strongest character developed in TK Kanisius, since these values are part of Catholic values.

\section{REFERENCES}

Cordner, C. (2016). Unconditional love? Cogent Arts \& Humanities, 3(1).

Creswell, J. W., \& Poth, C. N. (2016). Qualitative inquiry and research design: Choosing among five approaches. London: Sage publications.

Denscombe, M. (2014). The good research guide: For small-scale social research projects. New York:

McGraw-Hill Education.

Dewantara, K. H. (2011). Karya Ki Hadjar Dewantara (Bagian pertama pendidikan). Yogyakarta: Yayasan Pemersatuan Tamansiswa.

Fadlillah, M. (2012). Desain pembelajaran PAUD. Jogjakarta: Ar-Ruzz Media.

Hermans, C. (2017). Good education, the good teacher, and a practical art of living a good life: a Catholic perspective. Journal of Beliefs \& Values, 38(1), 77-88.

Hidayati, N. (2012). Bullying pada anak: Analisis dan alternatif solusi. Jurnal Insan, 14(1), 41-48.

Lickona, T. (2012). Character Matters (Persoalan Karakter). Jakarta: Bumi Aksara.

Moleong, L. J. (2011). Metodologi penelitian kualitatif. Bandung: PT. Remaja Rosdakarya.

Muslich, M. (2011). Pendidikan karakter: menjawab tantangan krisis multidimensional. Jakarta: Bumi Aksara. 
Olweus, D. (1993). Bullying at school: What we know and what we can do. Oxford, England: Blackwell.

Presiden. (2003). Undang-undang Nomor 20, Tahun 2003, tentang Sistem Pendidikan Nasional.

Samani, M., \& Hariyanto, M. S. (2012). Konsep dan model pendidikan karakter. Bandung: Remaja Rosdakarya.

Saptono, M. P. (2011). Dimensi-dimensi pendidikan karakter, wawasan, strategi, dan langkah praktis. Jakarta: Esensi Erlangga Group.

Semiawan, C. R. (2008). Belajar dan pembelajaran prasekolah dan sekolah dasar. Jakarta: Indeks.

Soegeng, A.Y., Abdullah. G., \& Kasihadi. (2016).

Landasan pendidikan karakter. Yogyakarta: Magnum Pustaka Umum.

Sugiyono, D. (2010). Metode penelitian kuantitatif dan $R \& D$. Bandung: Alfabeta.

Sujiono, Y. N. (2013). Konsep dasar pendidikan anak usia dini. Jakarta: Indeks.

Suyadi \& Ulfa, M. (2013). Konsep dasar PAUD.

Bandung: PT Remaja Rosdakarya. 